\title{
Building an Asia-Pacific Peace Community from a Human Security Perspective ${ }^{*}$
}

\author{
SORPONG PEOU**
}

This paper argues that the development of a regional peace community requires a high degree of human security that only stable democratic states are capable of providing. It advances the concept of regional peace community and seeks to formulate and validate the proposition that people-centered democracies are stable and stable democracies make regional peace communities durable. Although much has been written about human security in East Asia, no serious effort has been made to make human security the key conceptual foundation of a regional peace community in the Asia-Pacific.

Keywords: Regional Security Community, Regional Peace Community, Human Security, People-Centered Democracy, Realism, Liberalism, Constructivism, ASEAN, Asia-Pacific

* This paper was presented as keynote address at the 2015 Asian Political and Political International Studies Association Congress, 11-12 September. I would like to thank the participants, and Metta Spencer, for their helpful questions and comments. I alone, however, am responsible for any factual errors that exist in this article.

** Professor, Ryerson University, Toronto, Canada;

E-mail: speou@politics.ryerson.ca

DOI: 10.16934/isr.17.1.201606.1 


\section{INTRODUCTION}

Since Cambodia, Lao and Vietnam fell into the hands of communist revolutionaries in 1975, quickly followed by the Khmer Rouge's reign of terror, the region has witnessed at least three miracles, the first of which is widely recognized: the East-Asian economic miracle. The second miracle remains less well known: the end of mass atrocities (Bellamy 2014). The third miracle continues to unfold, as former foes are still making efforts to become friends who seek to build regional institutions and communities. The Association of Southeast Asian Nations (ASEAN), for instance, declared 2015 to be the first year of its regional economic, cultural and political-security communities.

Unfortunately, such miracles do not always last, nor do they happen as often as we wish. More often than not, new miseries lurk behind miracles. In East Asia, new challenges have now emerged: the threat of China's rise, as perceived by other states in the region; the growing rivalry between or among great powers (China, Russia, Japan and the United States); territorial disputes in the East and South China Seas; military buildups (especially nuclear and naval modernization); and recent stock market crashes and, arguably, currency wars. These all threaten to erase the memory of every past miracle.

This paper argues that the development of an Asia-Pacific peace community requires a degree of human security that only stable democratic states are capable of providing. Although much has been written about human security in East Asia (Howe 2014, 2013; Peou 2009a), no serious effort has been made to make human security the key conceptual foundation of a regional peace community. One of the arguments being advanced here, however, poses a challenge to the "peace-throughprosperity" proposition that tends to ignore the dark side of wealth. Although democracy also has its own dark side (because states that embrace this type of government have a history of waging war against undemocratic states), democracies have a proven track record of success in building and maintaining regional peace communities. Thus, this article advances the concept of regional peace community and seeks to validate the following proposition: people-centered or human security-based democracies are stable, and stable democracies make regional peace communities durable. I will begin by reviewing the relevant arguments representing alternative theoretical perspectives peace building in East Asia.

\section{THEORETICAL ARGUMENTS: THE REGIONAL AND HUMAN SECURITY NEXUS}

The idea of a regional security community poses a theoretical challenge to traditional security studies, which has long been dominated by political realism. Proponents tend to be social constructivists (Adler and Barnett 1998a), who see 
two basic types of regional security community: amalgamated and pluralistic. Amalgamated security communities are highly centralized to the extent that states agree to relinquish their sovereignty in favor of supra-nationalism, whereas states in pluralistic communities retain their sovereignty but no longer find one another militarily threatening. In a nutshell, security community members cease preparing for war against one another and co-exist peacefully, effectively constrained by collective norms and identities (Adler and Barnett 1998b).

Security community is, in fact, peace community, for every effective security community is a "non-war" community (Wæver 1998). The European Union (EU) is the best example. Other scholars use the term "warm peace" to describe the European community (Miller 2005). Non-war community is a "peace community," primarily because the theoretical framework adopted in this paper is in line with Immanuel Kant's notion of "perpetual peace." Social constructivists tend to see a linear progression of three logics: Hobbesian, Lockean and Kantian, where "Kantian" states no longer wage war against one another and even behave self-sacrificially (Wendt 1999).

Whether a regional peace community exists in Asia is debatable. Clearly, social constructivists have long made credible arguments to that effect. Constructivists who specialize in Asian regional politics and security have observed regional elites' efforts at building security communities. Amitav Acharya (1991, 2001), for instance, is famous for advancing the thesis that the political elites in the ASEAN region have chosen to build a peaceable security community. His analysis appears to be empirically validated when the ASEAN members officially formed their community in 2015. Acharya $(2001,2013)$ makes the case that no arms raceis underway in the region. Others think ASEAN has played a central role in the Asia Pacific, "despite its lack of material power" (Caballero-Anthony 2014). Alastair Iain Johnston (2003) tested for the effect of socialization on state behavior, using the ASEAN Regional Forum as his focus of analysis, showing that member states developed "habits of cooperation" through "social back patting" and that regional cooperation is possible. China offers a good example of how states' interests change. Prior to joining the ARF, China had not been aware of what its interests were, and it was highly skeptical of multilateral mechanisms. That is no longer the case.

The critical question is not whether ASEAN has played a leadership role in establishing institutional networks, but whether its "leadership" role is independent of other variables. In spite of her defense of ASEAN centrality, for instance, Caballero-Anthony $(2014,581)$ concedes that "ASEAN clearly needs to work harder to build its own institutional capacity. This ultimately requires a combination of political will and considerable investment." Meanwhile new challenges to the ASEAN efforts at regional community building have emerged. Territorial disputes between Cambodia and Thailand turned violent, despite their being members of 
ASEAN (Pou 2013; Chachavalpongput 2012). Acharya $(2013,11)$ also identifies new security challenges. Defense spending in Southeast Asia has increased dramatically, with Singapore being "the highest spender with the most capable armed forces" (ibid 10). He attributes the growth of defense spending to a number of factors, such as intra-ASEAN disputes and tensions, domestic insurgencies and nontraditional sources of insecurity (such as insurgencies, piracy and terrorism) led some Southeast Asian states to spend more on defense.

Newly emerging trends in East Asia also challenge commercial liberalism positing that states that trade with one another are more likely to foster peaceful relations because of their shared interest in creating wealth (Rosecrance 1986, 1999; Kaysen 1998). Commercial liberals think that growing economic costs, contact and communication pacify trading states. According to them, states are interested in economic welfare rather than in warfare, and states that trade with one another become economically interdependent or integrated and do not attack the others. When states prosper, their citizens are also assumed to enjoy the benefits of socio-economic security. The ASEAN Economic Community (AEC), for instance, is compatible with commercial liberalism for it shares the capitalist idea that a single market and production base is more dynamic and competitive. This community is regarded as one of the three pillars supporting regional peace.

But commercial liberalism raises questions that still do not seriously undermine political realism, which contends that prosperity and economic interdependence do not make peace (Waltz, 2000; Mearsheimer 2001). When states become economically developed and prosperous, argue political realists, they become more protective of their wealth and often more aggressive as they seek to sustain or accumulate wealth. With their wealth and the need to protect and accumulate it, these states build up their military capabilities by adopting defensive and offensive strategies. This may lead to the security quandaries and security dilemmas driven by arms races. Commercial liberalism has also come under fire (Ripsman and Blanchard 1996). John Ravenhill $(2009,207)$ also remind us that "[t]he relationship between the growth of interdependence and a reduction in militarized conflict between states is at best a probabilistic one: no proponent of the liberal approach would be sufficiently naïve to assert that growing interdependence will assure peace." Chienwu Hsueh (2015) further argues that the capitalist (or peace-throughprosperity) trajectory remains "a conditional one." Peaceful cooperation among states continues as long as they continue to perform well on the economic front. But they tend to provoke territorial disputes when they are unable to maintain good economic performance.

The realists still have a valid point about the fact that the wealth that states have enjoyed also has its dark side. Wealthier states, they would argue, continue to modernize armed forces for various reasons, including affordability, wealth protection and accumulation, and preparation for bad times, especially when coopera- 
tion no longer works to their advantage. Wealth also tends to create inequalities within states and between them. As a result, states do their best to ensure prosperity and prepare for the worst when cooperation no longer sustains economic growth and when their access to dwindling resources is denied. Neoliberal, network and normative institutionalist perspectives as well as commercial liberalism thus can explain some positive security developments in the Asia Pacific region, but their explanatory power remains limited (Peou 2010).

The greatest challenge to social constructivism, political realism and commercial liberalism comes from the democratic-peace thesis, which posits that democracies have almost never gone to war against one another. This does not mean that democracy is always prone to peace. There is definitely a dark side to democracies - something that realists are also quick to point out when explaining the recent Russian-Western fall-out. John Mearsheimer (2014), for instance, blames the West, especially the United States, for the crises in Ukraine that led to confrontations with Russia, because of the West's naïve liberal agenda. For democratic liberals, this realist view confirms their thinking about democracies' unvarying distrust of dictatorships, seeing them as sources of threats and thus being likely to go to war against them (Doyle 1996, 1997; Russett 1996).

Some realists acknowledge that democracies are less likely to go to war against one another. Aaron Friedberg (2011), as will be elaborated later, predicts peaceful relations between China and the United States if the former becomes democratic. Kaplan (2014) addresses the role of Asian modernizing autocrats and the end of instability in the South China Sea. The European Union is possible because its members are democratic.

Although the idea of liberal democracy and peace is not prominent in Alexander Wendt's constructivist thinking, his point that "500 British nuclear weapons are less threatening to the United States than 5 North Korean nuclear weapons" (Wendt 1998, 418) also demonstrates an axiom of democratic liberalism. Both the United States and Britain are democracies, whereas North Korea remains one of the worst dictatorships the world has ever known. This point is in line with Immanuel Kant's vision of perpetual peace (Bradshaw 2015). Democracies trust one another and can cooperate because of their shared norms and institutions (Doyle 1996, 1997; Russett 1996).

Most importantly, democratic liberals think that democracies tend to experience political stability-a major reason why their leaders do not need to intervene militarily or invade one another. The democratic liberal theorist Bruce Russett (1996, 89), for instance, makes a compelling case that "Perhaps the inherent stability that characterizes many democratic political systems accounts for their low rate of conflict with other democracies." His idea of democratic stability can be further expanded to help us explain why established democracies are more likely than undemocratic states to succeed in building and maintaining peace communities. 
First, democratic liberals and social constructivists think that power matters (Adler and Barnett 1998a, 1998b; Russett 1998, 366). Regional leadership provided by powerful democracies is crucial in the process of peace community building and maintenance. The existing peace communities are not without powerful democracies in their midst, and powerful democracies tend to be satisfied with the territorial status quo. The French-German economic alliance, for instance, has made it possible for the Europeans to achieve unification and strengthen their union (Gilpin 2003). The European and North American communities have benefited from the role of American leadership (Layne 2003). Democratic leaders provide collective goods for community members and keep recalcitrant members in line. Democracy and liberalization under US hegemony helped states in Europe integrate themselves into a "war peace" community (Miller 2005). Democratic leadership remains crucial throughout the process of community building and maintenance - a model advanced elsewhere (Peou 2002, 1998).

Second, democratic states tend to resolve their conflicts by relying on means short of war. There is evidence suggesting that they tend to be conservative powers, usually satisfied among themselves with the territorial status quo (Mitchell and Prins 1999; Kacowicz 1995). Evidence further shows that established democracies have few territorial disputes with one another and rarely have territorial disputes with their neighbors, because territorial disputes are difficult to win or resolve and democratic leaders fear electoral punishment (Gibler and Miller 2013). Democracies also have a history of disputes over fisheries, maritime boundaries and resources of the sea, but are able to remove territory as a contentious issue among them. Disputes between well-established democracies have also become less severe and shorter over time.

If stable democracies enjoy a relatively low rate of conflict among themselves, it is also because they can manage their territorial conflicts peacefully and are likely to demilitarize their common borders. The North American experience of community building specifically shows that democracies cannot build and enhance mutual trust until they agree to leave their long borders undefended or demilitarized (Shore 1998).

Only when democratic states find constructive ways to demilitarize their borders can they learn to find one another less threatening and more trustworthy. Defense spending can then be reduced to levels where states feel secure. Empirically, the EU democracies have gradually become less dominated by their armed forces. Evidence also shows that they have reduced defense spending, and many of them have even shifted from compulsory military service to all-volunteer forces because they have had difficulty recruiting and retaining military personnel. Democracy, among other things, helps explain this difficulty. As Tibor Szvircsev Tresch and Christian Leuprecht $(2010,7)$, for instance, put it, "While the electorates tend to support their armed forces and the idea of peace and stability operations in 
principle, they are often ambivalent about the financial and human cost of actual missions." This does not mean democracies are always against militarism but that they are likely to remain heavily militarized as long as they still face the threat of war posed by authoritarian states.

This brings me back to the point that regional peace community building is not possible until all states become stable democracies. Russett $(1998,373)$ makes this relevant point: stable democracies are those that guarantee minority rights against majority tyranny, have means of peaceful conflict resolution, and are not economically impoverished. These points can be further expanded. First, democracies can be stable as long as their institutions are highly developed; fair and open competition is the norm; political polarization and factionalism can be prevented, and executive authority can be substantially constrained (Goldstone and Ulfelder 2004). Democratic governance is not only about holding regular free and fair elections but also about maintaining institutional checks and balances, as well as protecting civil liberties (Peou 2015). Democratically elected governments are civilian, not subject to the prerogatives of their armed forces. People enjoy civil liberties, which limit state power and empower people. Most interesting about the EU is that its members commit to the protection of their peoples through judicial means such as an independent judiciary and autonomous legal institutions. Soon after the Second World War, the new democracies of Europe took human rights very seriously. Asplund $(2014,192)$ points out that they "wanted a strong and independent human rights body in order to stave off domestic, undemocratic forces, mitigating potential threats to their newly won democratic orders."

Although ideas and identities matter a great deal in global politics, it does not mean that relations among democracies are always trouble-free. They still engage in disputes and use rhetorical strategies to discredit one another, but they also use representational strategies to restore broken relationships (Bially Mattern 2004).

Russett also agrees that democracies with income levels of $\$ 6,000$ (1985 dollars) or higher "can be expected to live forever" (Russett 1998, 376). Thus, modernization scholars may be right when saying that economically developed democracies are likely to endure (See Wucheperpfenning and Deutsch 2009, for a review of this literature). Poor democracies are historically unstable, and the EU's experience shows that its member states sustain economic development, which helps reinforce faith in democracy, cooperation and trust building (Ripsman 2005; Miller 2005). This point further reinforces the liberal argument that democracies have a history of ensuring social stability: democracy prevents mass starvation (although they may be unable to defeat day-to-day hunger or poverty) and helps contribute to the expansion of basic human capabilities (Drèze and Sen 1989). Greater democracy also makes people less vulnerable to premature mortality (McGuire 2010) and thus enhances social stability.

In short, stable democracies may be generally characterized as "full-blown," 
"established" or "pluralistic" (Miller 2005); however, this article argues that stable democracies are first and foremost people-centered because democratic regime stability rests heavily on political legitimacy. Political legitimacy is what makes democracies stable, but democratic stability also rests on institutional and social stability.

The arguments advanced so far support the proposition that regional peace community building and maintenance rests on the idea of human security that only stable democracies can ensure. Human security has been defined in two distinct ways: narrow or protection-based, and broad or development-based. The protectionbased approach emphasizes freedom from fear (from direct and physical violence) that stable democracies can ensure. The development-based approach gives priority to freedom from want (from indirect or non-physical or structural violence). The UNDP approach places emphasis on human development and has become influential in Asia, especially in economically developed states like Japan. The UNDP and Japanese models are somewhat similar because they give top priority to human development propelled by the high economic growth experienced by states in East Asia (Peou 2014). This approach may have been influenced by commercial liberalism; however, as noted earlier, commercial liberalism has difficulty explaining why trading states have a history of going to war against one another and may not guarantee human protection. Thus, the protection-based approach provides an additional solid foundation for regional peace community building, but only stable democracies can achieve this goal because of their people-centeredness.

\section{PEACE COMMUNITY BUILDING BASED ON PROSPERITY?}

The Asia Pacific offers an excellent example of why the arguments advanced by various institutionalists and commercial liberals have limitations. The idea of security community building remains vibrant, but high expectations have been only partly met.

Although the ASEAN states have agreed to take steps toward implementing their regional community agenda, the gaps between rich and poor members remain an ongoing challenge to their collective vision. Cambodian support of an economic community, for instance, still rests on several difficult conditions. The Cambodian case sheds light on this challenge (Peou 2016). Economic growth has left certain sections of the population marginalized, and globalization has given rise to transnational organized crime in the region. The East Asian economic miracle has lifted hundreds of millions of people out of poverty, thus increasing their freedom from want, but people in this region remain insecure. As an ongoing source of threat to people, transnational organized crime has also risen alongside uneven economic growth and development and has not made states effectively cooperative in their commitment to combating nontraditional threats. 
Economic success also does not automatically make states cooperative on the politico-security front either. Territorial disputes between Cambodia and its neighbors, especially Thailand, turned violent despite their economic development (Pou 2013; Chachavalpongput 2012). Economically, successful states are likely to spend more on national defense, thus reinforcing traditional security concerns, such as enhancing their national security in general and furthering economic development or sustaining prosperity. Robert Kaplan (2014) further observes that development in East Asia is not about building high rises and new shopping malls but also about making warships and missiles. Kireeva $(2014,35)$ also makes this observation: "Modernization of the naval forces in Asia-Pacific countries began in the 1980s in parallel with an increase in defense spending" and successful economic development has led them "to build up their military potential in parallel with economic growth and modernization of their armed forces." With economic growth, states enjoy prosperity and spend more of their wealth modernizing their armed forces. With continued economic growth, Indonesia tripled its defense spending between 2001 ( $\$ 1.9$ billion) and 2012 (\$7 billion). If Singapore is the largest defense spender in Southeast Asia (with an annual defense budget close to $\$ 10$ billion), it makes sense to recognize that this city-state is also the most economically developed or the wealthiest among the ASEAN members. Evidently other states in Southeast Asia have increased their defense budgets and sought to build and expand their defense industries, viewing this strategy as part of their overall goal to further industrialization and economic development. Although its defense industries are not primarily viewed as part of its economic development strategy, Singapore has built "up the largest arms industry in Southeast Asia" (Bitzinger 2013, 383) and began "to commercialize and also globalize its defence business" in the mid-1990s (ibid, 382).

Economic growth and military buildup have not made it easier for states to resolve their territorial disputes either. Overlapping territorial disputes in the South China Sea have escalated in recent years, although these disputes are between China and other ASEAN states, particularly Vietnam and the Philippines. During the second half of the 2000s, tensions rose again. China again became more and more assertive. In January 2005, Chinese ships fired on two Vietnamese fishing boats, killing nine people. One boat with eight people onboard was detained on Hainan Island. Beijing accused them of being pirates and opening fire first. In March 2009, people aboard the Chinese ships waved their national flags and demanded that the US ship leave the area. The year 2011 saw armed clashes between Chinese ships and those of other claimant states. A dispute flared up again late in 2012 when Vietnam accused a Chinese fishing boat of cutting a seismic capable attached to a Vietnamese vessel exploring for oil and gas in the Gulf of Tonkin. Beijing defends the position that only it has the right to develop energy resources in the South China Sea. Tensions between China and the Philippines 
have now grown worse. In June 2011, Manila referred to the South China Sea as the "West Philippine Sea" and the Reed Bank as "Recto Bank." The year 2012 saw things turned for the worse, as their dispute over the Scarborough Shoal intensified. Manila accused China of illegally laying 75 concrete blocks on the chain of reefs and rocks along the Shoal. In July, a frigate of the Chinese navy ran aground in an area within the Philippines' EEZ. In January 2013, Manila took further action against China by filing a complaint with the International Tribunal for the Law of the Sea-an independent judicial body established to settle maritime disputes. Beijing objected to the move made by Manila, making it clear that the international body has no jurisdiction over maritime areas, and that any of its attempts to get involved in maritime disputes would jeopardize the principle of state sovereignty. For the Philippines, China disregards rules established in international law allowing states to enjoy their 322 nautical-km Exclusive Economic Zones.

There is a similar pattern in China's assertive activity in the East China Sea. Territorial disputes over Senkaku (called Diaoyu by the Chinese) between China and Japan have also intensified in recent years. In May 2013, the Communist Party newspaper, The People's Daily, published an article by two Chinese scholars making the case that the Ryukyu chain of islands, which includes Okinawa, does not belong to Japan. According to them, Japan annexed the Ryukyu kingdom in 1879 and this amounted to an invasion. Ryukyu's sovereignty status thus remains open to debate (McCurry 2013).

China's territorial assertiveness has resulted from at least two major factors that reinforce each other: military modernization and economic growth. Its military buildup continues unabated at an alarming rate. There is a correlation between economic growth and increased defense spending, although data on defense spending is always subject to dispute. Between 1996 and 2006, according to some observers, China spent an annual average rate of $11.8 \%$ on defense, while the economic growth rate was about 10\%. Between 2007 and 2012, the annual average rate was even higher, jumping from $\$ 45$ billion to $\$ 106.4$ billion. According to some estimates, China's military budget in 2015 would surpass that of all 12 Asian-Pacific neighbors (Richburg 2012). According to a more recent report: China spent $\$ 176$ billion in 2014 and $\$ 190$ billion in 2015. The Chinese government is set to spend around $\$ 260$ billion in 2020 (Barnato 2015).

Without wealth accumulated over the past 30 years, China could not have increased defense spending and modernized its defense system to the extent that it has been able to do. According Friedberg (2011), "evidence of China's expanding capabilities and ambitions has continued to accumulate." China has also become more politically ambitious. Since the global financial crisis that erupted in 2008-9, China's leaders have become more assertive than ever before. They have become more willing to resist external pressures for change, are more open about their country's rapidly evolving military capabilities, are "blunter in warning its neigh- 
bors against opposing its wishes, more willing to use its growing economic clout in an attempt to exert diplomatic leverage, and more open in questioning the likely longevity of America's leading role in Asia and the world" (Ibid, xvi). As "wealth and power at its command have grown, Beijing has begun to exert increasing influence, both in Asia and around the world" (ibid, xv).

With its growing military might, China has shown no sign of trying to hide its ambition to become the preeminent power in Asia. On 3 September 2015, Beijing staged one of the most impressive shows of force in front of world leaders such as Russian President Vladimir Putin and UN Secretary-General Ban Ki-moon. More than 12,000 troops, some 500 pieces of military hardware and 200 military aircraft were involved in the parade, sending the message that China was ready to fend off anything its leaders would consider armed aggression. The military parade also came at a time when the Chinese economy showed signs of slowdown and after the Chinese stock markets had crashed, and the country was likely to experience social and political instability. Economic problems and poor economic performance may thus prevent state elites from socializing for peace and may encourage them to flex their military muscles, especially when they feel threatened by other powerful states, democratic or otherwise.

While it makes it possible for states to modernize their armed forces, economic growth also makes their armed forces more threatening amid a growing demand for limited natural resources and competition over dwindling resources. Competition for control over natural resources in the East and South China Seas are likely to intensify as states in the region have procured submarines, warships and antiship missiles as they continue to defend their maritime claims and adopt the strategy of "anti-access/area denial" (A2/AD). Southeast Asian states have purchased A2/AD weapons "to deny China's freedom of movement in the South China Sea" and China "has pursued an A2/AD strategy to deter and potentially defeat the far superior naval capabilities of the US" (LeMière 2014, 145, 147). Over the few decades the Chinese A2/AD strategy "will enable China to block the US ability to project power" in East Asia (Kireeva 2014, 40).

In the midst of economic growth and military modernization, many states in the Asia Pacific, including most ASEAN states, remain insecure and continue to "welcome the United States as an external balancer to China's rise" (Chang 2014, 390). This has intensified the rivalry between China and the United States, which has now sought to rebalance China. Beijing has in turn criticized the United States and its regional allies for their attempt to preserve American dominance over the region (Kireeva 2014, 37). What this suggests is that the idea of ASEAN being a security community is still problematic because of its dependence on great powers for its development and security.

Some scholars even predict a coming cold war between China and the United States, because "China's recent procurement of [defense] systems ... fall within 
offensive power projection" (Ikegami 2009, 6). Tieh-shang Lee (2011) provides a statistical analysis of China's rising military power and predicts the probability of war between China and the United States occurring around the years 2063-2079. Data shows that between 1990 and 2005 China's military power still lagged behind that of the United States and that China's level of dissatisfaction was not extremely high, thus explaining China's peaceful behavior. Potential war between them remains, however.

In short, economic growth has both encouraged and limited prospects for regional peace community building. Economic development has made states and their peoples in the region more prosperous, but it has also contributed to socialeconomic inequalities, a major source of instability. Because of their growing wealth, states have also spent more on defense. Territorial disputes also resulted from its military modernization, driven by prosperity. Thus, the most critical question is: Why economic growth/development in East Asia has not produced the positive effects predicted by commercial liberals and proponents of development-based human security? The answer may lie elsewhere.

\section{WHY DEMOCRACY MATTERS}

This section advances the argument that democracy matters significantly in terms of making a positive impact on collective efforts at regional alliance and community building. This does not suggest that democracy is a panacea for every source of regional and human insecurity. Still, democracy remains the best form of government that encourages states to make a collective effort to build regional peace communities.

Historical evidence clearly shows that authoritarian states or their leaders in the Asia-Pacific do not have a proven track record of success in maintaining their politico-military alliances, not to mention a single regional peace community. They were able to form military alliances among themselves (i.e., the Soviet Union/ Russia, China and other Southeast Asian states like Vietnam), but their alliances were still a reflection of their national interests-- and extremely fragile. Only when faced with a common threat did they find it possible to form alliances; however, when the threat they shared disappeared, their alliances weakened or collapsed. The Sino-Soviet and Sino-Vietnamese politico-military alliances, initially formed to confront Western imperialism, had collapsed long before the Cold War ended. Two communist states in Indochina, Cambodia and Vietnam, turned against each other soon after their communist movements defeated their enemies in the mid1970s. Undemocratic states still behave as expected by political realists. The Chinese and Vietnamese political elites still regard themselves as communist, but their broken alliance has never been restored. Vietnam has, in fact, moved much closer to the United States than to China. China remains a lonely superpower because 
it does not have any real military ally.

Democratic and undemocratic states also have a long history of mutual distrust and have waged war against one another. Today in Northeast Asia, the possibility of war between undemocratic and democratic states remains strong: between communist North Korea and democratic South Korea; communist China and democratic Taiwan (Wang 2002), communist China and democratic Japan; China and the United States (the world's second largest democracy); Russia and the United States (Mead 2014).

There are still serious challenges to building a security community in Southeast Asia, as the ten member states have a mixture of democratic and authoritarian regimes. Although ASEAN's conscious efforts to build a people-oriented political community represent a positive step, the regional group is still made up of weak or immature democracies (such as Indonesia, the Philippines and until recently Thailand), illiberal democracies (Malaysia and Singapore), and electoral democracies (Cambodia) and undemocratic states (Laos, Myanmar and Vietnam) (Peou 2015). This mixture of political regimes in ASEAN has made it difficult for the member states to reach consensus on liberal norms and build a common identity (Asplund 2014; Davies 2014). A realist, Robert Kaplan also recognizes that ASEAN "is not at the level of integration of the European Union (EU), which is united by a common form of government-democracy-giving it a philosophical, and hence, reason d'être" (Kaplan 2014, 74).

Undemocratic states, such as China and North Korea, enjoy limited or no political legitimacy and thus have had to resort to nationalism/militarism as a way to make their regime look legitimate. Authoritarian leaders operate on the basis of hierarchy, secrecy and repression and "are likely to perceive the outside world as hostile and threatening and are likely to encourage their citizens to hold similar views" (McCormick 2000, 325). China's anti-Japanese nationalism and its Sinocentric chauvinism remain powerful hindrances to genuine China-Japan reconciliation. The absence of democracy in China has contributed to its misunderstanddings of Tokyo, made "Chinese patriots" blind to their past hegemonic ambitions, thus perpetuating Japan's security dilemma (ibid, 118-119). China's non-democratic nationalism has also been unattractive to Taiwan. McCormick $(2000,325)$ cautions that "Authoritarianism does not make conflict between China and the United States inevitable, but it does significantly increase its likelihood." If the two powers have not waged war with each other, it is because China is no match for the United States, although Chinese military expenditures are closing the gap.

Aaron Friedberg $(2011,1)$ further contends that what has kept China and the United States "locked in a quiet but increasingly intense struggle for power and influence" is not simply "the result of easily erased misperceptions or readily correctible policy errors." Their rivalry "is driven instead by forces that are deeply rooted in the shifting structure of the international system" and in their "very 
different domestic political regimes." The two powers have different political systems. As a democracy, the United States has sought a regime change in China, but the latter has sought to preserve its authoritarian system by pushing back and seeking to displace the former as the preponderant power in East Asia. This has created a major source of mistrust between them. Political compromise is unlikely, as each thinks history is on its side.

Evidence from the Asia Pacific shows peaceful relations among democracies in the form of bilateral military alliances: between Japan and the United States, South Korea and the United States, Thailand (an institutionally weak democratic state until recently) and the United States, the Philippines (still a weak democracy) and the United States; as well as Australia and the United States. These bilateral security alliances were formed during the Cold War and remain more or less strong today. As the case of the Philippines and the United States demonstrates, democracies do not have a perfect record of maintaining alliances, but they are still capable of restoring them and maintaining peaceful relations.

Even when they do not form alliances among themselves, democracies can mitigate war-prone behavior toward one another. As democracies, India and the United States never went to war against each other during the Cold War. Edward Friedman cites examples of how democratic states in Pacific Asia have achieved genuine reconciliation, based on trust, transparency, and cooperation (Friedman 2000). Friedman was quite aware of the continuing difficulties between Korea and Japan, but "Seoul and Tokyo could still devise democratic ways of resolving issues in textbook disputes as authoritarian China cannot" (ibid, 113). A democratic China would be able to promote debate that could enable its patriots to pay "attention to millennia of Chinese wars of incorporation and expansion" (ibid, 109) and could help them understand others better, because of "the complexities of openness and transparency" (ibid, 113).

Even political realists like Arron Friedberg, Kenneth Pyle and Robert Kaplan still regard power transition among democracies as less prone to war than that between undemocratic powers (Pyle 1997, 46, 51). For Friedberg (2011, 251-252), the United States must prepare itself for the worst until China becomes a democracy, for only then can the former learn to live with the latter as the preponderant power in East Asia and call home its legions. His analysis incorporates liberal democratic insights. In his words: "If we permit an illiberal China to displace us as the preponderant player in this most vital region, we will face grave dangers to our interests and our values throughout the world" (ibid, 8). Friedberg thinks that only democracies can coexist peacefully. The European experience further suggests that "nationalist passions, territorial disputes, and arms races [over there] were fast dwindling into historical memory" (ibid, xiii). According to Kaplan $(2014,163)$, "China today becomes less and less autocratic and less and less centralized" and the United States should "be prepared to allow, in some measure, for a Chinese 
rising navy to assume its rightful position" (Kaplan 2014, 182) when it becomes democratic, just as Britain was prepared to let the United States become the next hegemon over the Caribbean. Evidence shows that power transition between powerful democracies, such as the United Kingdom and the United States, is less prone to war than power transition between democracies and dictatorships or between authoritarian states.

This does not suggest that relations among states like the United States and the United Kingdom or other European states are problem-free. As noted by Janice Bially Mattern (2004), for instance, the special relationship between Washington and London broke down over their differences on how to deal with Egypt's nationalization of the Suez Canal in 1956, but the two democratic states managed to patch up their differences by employing representative strategies to reestablish a collective "we."

Until China becomes democratic, prospects for peace-community building in Southeast Asia or the Asia Pacific remain grim indeed. As long as China remains undemocratic, its leadership is unlikely to work effectively toward settling maritime disputes over the East and South China Seas. The authoritarian leadership in Beijing is most likely to remain aggressively revisionist, seeking to change international rules and making territorial claims that clash with other states. These are among the most critical factors that would allow it to justify its high concentration of power, to build stronger armed forces by increasing taxation and defense spending, to suppress domestic discontent, and to whip up nationalist sentiment. A democratic China, however, would put more pressure on its leaders to settle territorial disputes because its leaders would feel less threatened from other democracies, such as the United States, and would subsequently be more willing to behave less aggressively or even to accept the fact that waging a war that they would not easily win could be costly to them in electoral terms. Insights from territorial peace literature further show that "democratic leaders seldom have disagreements over homeland territories, which are disputes that are difficult to win, difficult to resolve, and last longer than disputes of other types" (Gibler and Miller 2012, 259). A democratic China would less likely wage war over territorial disputes in the East or South China Sea, especially if the United States were to defend other state claimants. The United States is also most unlikely to initiate a war against China because the latter is so strong that it cannot militarily defeated. It is worth noting that the United States has proved unable to defeat the Taliban forces in Afghanistan or the Islamic state in the Middle East. A democratic China at territorial peace with other democracies is more likely to spend less on defense, lower their taxation levels and enhance security for their people.

Until China is transformed into an established democracy (and Russia for that matter), democratic states in the Asia Pacific will not only continue to depend on the United States as regional stabilizer but also continue to seek building 
military alliances. In 2012, for instance, Japan proposed creating a multilateral security alliance made up of major democracies (Australia, India, Japan and the United States) in the form of an "Asian security diamond." According to Japanese Prime Minister Shinzo Abe, who formulated the strategic concept, "The ongoing disputes in the East China Sea and the South China Sea mean that Japan's top foreign policy priority must be to expand the country's strategic horizons. Japan is a mature maritime democracy and choice of close partners should reflect that fact." In his words: "I envisage a strategy whereby Australia, India, Japan, and the US State of Hawaii form a diamond to safeguard the maritime commons starting from the Indian Ocean Region to the Western Pacific. I am prepared to invest the greatest possible extent, Japan's capabilities in the security diamond." The prime minister has reached out to other European democracies such as France and Britain, which are said to "have significant strategic, political and economic stakes in the Indian Ocean Region and also the Western Pacific" (Kapila 2014).

The realist question about the fact that democracies in the Asia Pacific have not transformed their bilateral security alliances into multilateral military alliances like NATO, or a security community like the EU, is difficult to answer. Part of the problem with democratic states in East Asia is that they are not as liberal as they should be in terms of respect for individual rights and liberties (Dressel and Bünte 2014; Majid 2010). Some scholars, for instance, argue that "in the cases of Indonesia, Thailand, the Philippines [...] the military has remained a significant feature of the state apparatus, either dominating or sustaining order within society" (Ganesan and $\operatorname{Kim} 2013,15)$.

How exactly democratic state elites in the Asia Pacific would build and maintain a peace community remains to be seen, and more research is necessary. Historical evidence, however, provides only some important clues. First, democracies do not create peace communities overnight. Their dependable expectations of peaceful change develop over time, as the result of various factors including their shared perception of threat from undemocratic states. Second, democratic states, especially powerful ones such as France and Germany, managed to achieve reconciliation and build regional institutions (Ripsman 2005). Leaders of powerful democracies in the Asia Pacific may also need to take the lead and articulate a sense of common purpose centered on the idea of community based on mutual trust. A democratic China and other major democracies (namely Australia, Indonesia, Japan and the United States) would be able to establish at least a concert of powers providing collective goods, perhaps a stepping stone toward a community.

Third, regional peace communities grow mature when their members are stable democracies fully embracing the idea of human security. In East Asia, only a handful of states, namely Japan and Thailand, officially endorsed the human security agenda, but they still gave priority to human development. Their democracy has recently come under threat. Thailand's current military rule works against the 
idea of protection-based human security. The quality of Japanese democracy has also declined. Subsequent governments in Tokyo have faced a political legitimacy crisis and Japanese nationalism has been on the rise. Japan's "historical revisionism" is also justified by the China threat.

Thus, the long-term challenge to Asia-Pacific peace community building lies in successful democratic consolidation to the extent that people are satisfied with government performance and that the armed forces are subject to effective democratic control. Many of the democracies in East Asia are either electoral or illiberal, usually subject to the control of the unelected elites such as those of the armed forces. Even in more liberal democracies like Taiwan, people have grown discontent (because the political and economic elites have manipulated the systems to their own benefit) and want a democratic system that would benefit people (Schafferer 2015).

A regional peace community in the Asia Pacific would still be different from the EU and North America, however. Unlike European and North American democracies that are in geographical proximity and share land borders, Asian democracies like Japan, South Korea and Taiwan are separated by vast bodies of water. Japan, South Korea and Taiwan are also thousands of miles away from other democracies in Southeast Asia, mainly the Philippines and Indonesia. While seas help keep states from threatening or invading one another, they may also help prevent democracies from developing a greater sense of community than if they were geographically close to one another as democracies in the EU and North America. Democracies in the Asia Pacific are likely to become less like the highly centralized or amalgamated EU peace community and more like the NorthAmerican peace community that remains pluralistic. None of the democracies in the Asia Pacific is now prepared to give up its state sovereignty to the extent that the EU members have, and indeed an Asia-Pacific peace community is most likely to become more pluralistic than the North-American community. Separated by seas, they may never be as close to one another as the United States and Canada.

\section{CONCLUSION}

This paper has made the case that states in the Asia Pacific may one day be able to establish a regional peace community. Part of this optimism rests with the reality that efforts to build a regional peace community in ASEAN have become more evident in recent years, but this political project is unlikely to reach maturity for various reasons. The idea of ASEAN community building was still on the right track when the ASEAN Secretariat stated in 2009 that the people and members of ASEAN "will live in peace with one another and with the world at large in a just, democratic and harmonious environment." The questions are whether this common vision will come to pass soon and how many ASEAN states are truly democratic. 
The most critical challenge is realizing that this ultimate vision is rooted in neither peace through military power nor through just economic growth or development. Economic development and prosperity are the major factors contributing to the process of military modernization in East Asia and to the escalation of territorial disputes. The great challenge to regional peace community building lies in repeated efforts by authoritarian states to suppress dissent, and weak democracies are unable to protect political rights, civil liberties and other human rights. ASEAN is still made up of members that are weak democracies and strong authoritarian states. Indonesia remains a young democracy and is unlikely to provide effective leadership any time soon, because most of the other ASEAN members are undemocratic and unprepared to accept its leadership. China remains undemocratic and thus poses a challenge to the ASEAN community project. ASEAN is unlikely to become a peace community because of its heavy dependence on the United States as guarantor of regional stability. The United States has been unable to lead the region because of strong opposition from undemocratic states. ASEAN will have a better chance of transforming itself into a peace community when its authoritarian states and China become democratic. But if and when this happens, ASEAN will definitely become part of a larger peace community led by powerful democracies (China, Japan and the United States).

The greatest challenge to community building in the Asia Pacific lies in states' insufficient will to protect and empower their people because of the ongoing worries about state security in the midst of growing military and nonmilitary threats. By seeking to ensure more security for themselves or their regimes, states or their leaders leave their people less secure, thus enjoying less political legitimacy, and end up being less stable and more insecure. Democratic states that secure their people help avoid this insecurity dilemma-a condition under which states that pay more attention to their security pay less attention to the security of their people, but this asymmetrical attention (more state-centric than human-centered) prevents them from successfully building peace communities aimed at alleviating the classic security dilemma (which develops when states that seek to enhance their security end up being threatened by other states that also seek to secure themselves). For only when people are more secure can their states become more stable, and only stable states can make regional peace communities durable. Only the type of democracy that protects and promotes individual freedom appears to enable the process, but this system of governance persists when power-holders are institutionally constrained, when the armed forces are subject to only democratically elected civilian leadership, and when people can at least enjoy freedom from fear.

My theoretical proposition-that people-centered democracies are stable and that stable democracies make durable peace communities-has strong empirical support and remains defensible. But historical evidence may not always be able to validate all future events, especially when democratic states no longer face autho- 
ritarian threats. Stephen Walt (1999) offers some useful caution, but a world of established democracies is likely to be more conducive to regional peace community building, especially when there is a strong leader among them (Peou 2009b). Unfortunately, democracy now appears to "run into trouble" despite the fact that it "was the most successful political idea of the $20^{\text {th }}$ century" (The Economist 2014). Thus, keeping "the world safe for democracy," as advocated by US President Woodrow Wilson, remains an urgent task for policymakers and peacebuilders, but making democracy safe for people is even far more urgent.

\section{REFERENCES}

Acharya, Amitav. 2013. ASEAN 2030: Challenges of Building a Mature Political and Security Community. Tokyo: Asian Development Bank Institute, Working Paper Series, No.441, October.

Acharya, Amitav. 2001. Constructing a Security Community in Southeast Asia: ASEAN and the Problem of Regional Order. London: Routledge.

Acharya, Amitav. 1991. Association of Southeast Asian Nations: Security or Defence Community? Pacific Affairs 64(2): 159-178.

Adler, Emmanuel and Michael, Barnett, editors. 1998a. Security Communities. Cambridge: Cambridge University Press.

Adler, Emmanuel and Michael Barnett. 1998b. "A Framework for the Study of Security Communities." In Security Communities edited by Emmanuel Adler and Michael Barnett. Cambridge: Cambridge University Press.

Asplund, Andre. 2014. ASEAN Intergovernmental Commission on Human Rights: Civil Society Organizations Limited Influence on ASEAN. Journal of Asian Public Policy 7(2): 191-199.

Barnato, Katy. 2015. "China Defense Spending to Double in 2020: Report." CNBC September 2, accessed February 14, 2016, http://www.cnbc.com/2015/09/02/ china-defense-spending-to-double-by-2020-report.html.

Bellamy, Alex. 2008. "The Responsibility to Protect and the Problem of Military Intervention.” International Affairs 84 (4): 615-639.

BiallyMattern, Janice. 2004. Ordering International Politics: Identity, Crisis and Representational Force. New York: Routledge.

Bitzinger, Richard A. 2013. "Revisiting Armaments Production in Southeast Asia: New Dreams, Same Challenges.” Contemporary Southeast Asia 33(3): 369394.

Bradshaw, Leah. 2015. "Kant, Cosmopolitan Rights, and the Prospects for Global Peace." In The Question of Peace in Modern Political Thought edited by Toivo Koivukoski and David Edward Tabachnick. Waterloo, ON: Wilfred Laurier University.

Caballero-Anthony, M. 2014. “Understanding ASEAN's Centrality: Bases and Pro- 
spects in an Evolving Regional Architecture." The Pacific Review 27(4): 563-584.

Chachavalpongput, Pavin. 2012. "Embedding Embittered History: Unending Conflicts in Thai-Cambodian Relations." Asian Affairs 43(1): 81-102.

Chang, F. K. 2014. "Economic and Security Interests in Southeast Asia." Orbis 58 (3): 378-391.

Davies, M. 2014. “An Agreement to Disagree: The ASEAN Human Rights Declaration and the Absence of Regional Identity in Southeast Asia." Journal of Current Southeast Asian Affairs 33(2): 2-24.

Doyle, Michael. 1996. "Kant, Liberal Legacies, and Foreign Affairs." In Debating the Democratic Peace edited by Michael E. Brown, Sean M. Lynn-Jones, and Steven E. Miller. Cambridge, MA: MIT Press.

Dressel, Björn and Marco Bünte. 2014. "Constitutional Politics in Southeast Asia: From Contestation to Constitutionalism." Contemporary Southeast Asia 36(1): 1-22.

Drèze, Jean and Amartya K. Sen. 1989. Hunger and Public Action. Oxford: Clarendon. Friedberg, Aaron. 2011. A Contest for Supremacy: China, America, and the Struggle for Mastery in Asia. New York: W. W. Norton and Company.

Friedman, Edward. 2000. Preventing War between China and Japan. In What If China Doesn't Democratize? edited by Edward Friedman and Barrett L. McCormick. New York: ME Sharpe.

Ganesan, Narayanan and Sung Chull Kim 2013. "Introduction." In State Violence in Asia edited by Narayanan Ganesan and Sung Chull Kim. Lexington, KY: University Press of Kentucky.

Gibler, Douglas M. and Steven V. Miller. 2013. "Quick Victories? Territory, Democracies, and Their Disputes." Journal of Conflict Resolution 57(2): 258284.

Gilpin, Robert. 2000. The Challenge of Global Capitalism. Princeton, NJ: Princeton University Press.

Goldstone, Jack and Jay Ulfelder. 2004. "How to Construct Stable Democracies." The Washington Quarterly 28(1): 9-20.

Economist (2014). "What's Gone Wrong with Democracy?" March 1, accessed, http:/www.economist.com/news/essays/21596796-democracy-was-most-suc cessful-political-idea-20th-century-why-has-it-run-trouble-and-what-can-be-do.

Howe, Brendan, editor. 2014. Post-Conflict Development in East Asia. Surrey, UK: Ashgate.

Howe, Brendan. 2013. The Protection and Promotion of Human Security in East Asia. New York, NY: Palgrave Macmillan.

Hsueh, Chienwu. 2015. "ASEAN and Southeast Asian Peace: Nation Building, Economic Performance, and ASEAN's Security Management.” International Relations of the Asia-Pacific 2-40. 
Ikegami, Masako. 2009. "China's Grand Strategy of 'Peaceful Rise': A Prelude to a New Cold War." In Rise of China: Beijing's Strategies and Implications for the Asia-Pacific edited by Hsin-Huang Michael Hsiao and Cheng-yi Lin. London and New York: Routledge.

Johnston, Alastair Iain 2003. "Socialization in International Institutions." In International Relations Theory and the Asia-Pacific edited by G. John Ikenberry and Michael Mastanduno: Columbia University Press.

Kacowicz, Arie M. 1995. "Explaining Zones of Peace: Democracies as Satisfied Powers?" Journal of Peace Research 32: 265-76.

Kapila, Subhash. 2014. Japan's 'Asian Security Diamond': Strategic Concept Reviewed. South Asia Analysis Group 19 August, No.5770 accessed August 20, 2015, http://www.southasiaanalysis.org/node/1596.

Kaplan, Robert D. 2014. Asia's Cauldron: The South China Sea and the End of a Stable Pacific. New Yok: Random House.

Kaysen, Carl. 1998. "Is War Obsolete?" In Theories of War and Peace edited by Michael E. Brown. Cambridge, MA: MIT Press.

Kireeva, Anna. 2014. "Regional Strategies and Military Buildup in East Asia and Indo-Pacific: A Russian Perspective." Maritime Affairs 10(2): 33-51.

Layne, Christopher. 2003. "America as European Hegemon." The National Interest 72: 17-29.

Lee, Tieh-shang. 2011. "China's Rising Military Power and its Impact." In China's Quiet Rise: Peace through Integration edited by Baogang Guo and ChungChian Teng. Lanham, Maryland: Lexington Books.

LeMière, Christian. 2014. "The Spectre of an Asian Arms Race." Survival 56(1): $139-56$.

Majid, Munir. 2010. "Going through the Democratic Motions in Southeast Asia." International Politics 47(6): 725-38.

McCormick, Barret L. 2000. "U.S.-PRC Relations and the Democratic Peace." In What If China Doesn't Democratize? edited by Edward Friedman and Barrett L. McCormick. New York: ME Sharpe.

McCurry, Justin. 2013. "China Lays Claim to Okinawa as Territory Dispute with Japan Escalates." The Guardian.Com, 15 May, accessed September 14, 2013, http://www.theguardian.com/world/2013/may/15/china-okinawa-dispute-japanryukyu.

McGuire, James W. 2010. Wealth, Health, and Democracy: In East Asia and Latin America. Cambridge: Cambridge University Press.

Mead, Walter Russell. 2014. "The Return of Geopolitics: The Revenge of Revisionist Powers." Foreign Affairs 93(3): 69-79.

Mearsheimer, John. 2014. "Why the Ukraine Crisis Is the West's Fault: The Liberal Delusions that Provoked Putin." Foreign Affairs. September-October: 77-89. Mearsheimer, John. 2001. The Tragedy of Great Power Politics. N.Y and London: 
W.W. Norton and Company.

Mitchell, Sara McLaughlin and Brandon C. Prins. 1999. "Beyond Territorial Contiguity: Issues at stake in Democratic Militarized Interstate Disputes." International studies Quarterly 43: 169-83.

Miller, Benjamin. 2005. "When and How Regions become Peaceful: Potential Theoretical Pathways to Peace." International Studies Review 7(2): 229-67.

Peou, Sorpong. 2016. "Cambodia: From Isolation to Involvement in Regional Community Building." In Regional Community Building in East Asia: Countries in Focus edited by Lee Lai To, Nguyen Hong Son, and Zarina Othman. Routledge.

Peou, Sorpong. 2015. "The Limits and Potential of Liberal Democratization in Southeast Asia." Journal of Current Southeast Asian Affairs 33(3): 19-47.

Peou, Sorpong. 2014. Human Security Studies: Theories, Methods and Themes. Singapore and Hackensack, NJ: World Scientific and Imperial College Press.

Peou, Sorpong. 2010. Peace and Security in the Asia-Pacific: Theory and Practice. Santa Barbara, CA: Praeger.

Peou, Sorpong. editor. 2009a. Human Security in East Asia: Challenges for Collaborative Action. New York, NY and Oxon, UK: Routledge.

Peou, Sorpong. 2009b. "Security Community Building in Asia Pacific." In Re-envisioning Asia-Pacific Security: A Regional-Global Nexus? edited by William Tow. New York: Cambridge University Press.

Peou, Sorpong. 2002. "Regional Community Building for Better Global Governance." In The United Nations System in the $21^{\text {st }}$ Century edited by Volker Rittberger.Tokyo: United Nations University. Press.

Peou, Sorpong. 1998. "The Subsidiarity Model of Global Governance in the ASEANUN Context." Global Governance 4(4): 439-459.

Pou, Sothirak. 2013. "Cambodia's Border Conflict with Thailand." Southeast Asian Affairs. Singapore: Institute of Southeast Asian Studies.

Pyle, Kenneth. 1997. "The Context of APEC: U.S.-Japan Relations." In From APEC to Xanadu: Creating a Viable Community in the Post-Cold War Pacific edited by Donald C. Hellmann and Kenneth B. Pyle. Armonk, New York: M.E. Sharpe.

Ravenhill, John. 2009. "The Economics-Security Nexus." In Security Politics in the Asia-Pacific: A Regional-Global Nexus? edited by W. Tow. Cambridge, UK: Cambridge University Press.

Richburg, Keith B. 2012. "China Military Spending to Top \$100 Billion in 2012, Alarming Neighbors." The Washington Post. 4 March.

Ripsman, Norrin. 2005. "Two Stages of Transition from a Region of War to a Region of Peace: Realist Transition and Liberal Endurance.” International Studies Quarterly 49(4): 669-693.

Ripsman, Norrin and Jean-Marc Blanchard. 1996. “Commercial Liberalism under 
Fire: Evidence from 1914 and 1936." Security Studies 6(2): 4-50.

Rosecrance, Richard. 1986. The Rise of the Trading State: Commerce and Conquest in the Modern World. New York: Basic Books.

Rosecrance, Richard. 1999. The Rise of the Virtual State. New York: Perseus Books Group.

Russett, Bruce. 1998. “A Neo-Kantian Perspective: Democracy, Interdependence and International Organizations in Building Security Communities." In Security Communities edited by Emanuel Adler and Michael Barnett. Cambridge: Cambridge University Press.

Russett, Bruce. 1996. "Why Democratic Peace?" In Debating the Democratic Peace edited by Michael E. Brown, Sean Lynn-Jones, and Steven Miller. Cambridge, MA: MIT Press.

Schafferer, Christian. 2015. Taiwanese Democracy 2.0. Paper presented at the Congress of the Asian Political and International Studies Association, 11-12 September, Phnom Penh.

Shore, Sean. 1998. "No Fences Made Good Neighbors: The Development of the US-Canadian Security Community.” In Security Communities edited by Emanuel Adler and Michael Barnett. Cambridge: Cambridge University Press.

Tresch, Tibor Szvircsev and Leuprecht, Christian (editors). 2010. Europe Without Soldiers? Recruitment and Retention Across the Armed Forces of Europe. Montreal and Kingston, Canada: McGill-Queen's University Press.

Wæver, Ole. 1998. "Insecurity, Security, and Asecurity in the West European NonWar Community." In Security Communities edited by Emanuel Adler and Michael Barnett. Cambridge: Cambridge University Press.

Walt, Stephen. 1999. "Never Say Never: Wishful Thinking on Democracy and War." Foreign Affairs 78(1): 146-51.

Waltz, Kenneth. 2000. "Structural Realism after the Cold War." International Security 25(1): 5-41.

Wang, Yuan-kang. 2002. "Taiwan's Democratization and Cross-Strait Security." Orbis 43(2): 293-304.

Wendt, Alexander. 1999. Social Theory of International Politics. Cambridge, UK:

Cambridge University Press.

Wendt, Alexander. 1998. "Constructing International Politics." In Theories of War and Peace edited by Michael E. Brown, Sean M. Lynn-Jones, and Steven Miller. Cambridge, MA: MIT Press.

Wucherpfenning, Julian and Franziska Deutsch. 2009. "Modernization and Democracy: Theories and Evidence Revisited." Living Reviews in Democracy 1: 1-9. 